Article

\title{
Organic Beet Leaves and Stalk Juice Attenuates the Glutathione Peroxidase Increase Induced by High-Fat Meal in Dyslipidemic Patients: A Pilot Double-Blind, Randomized, Controlled Trial
}

\author{
Amanda Cristine de Oliveira ${ }^{1}$, Anna Paula Oliveira Gomes ${ }^{1}{ }^{(D}$, Lorena Charife Rodrigues ${ }^{1}$, Raisa da Silva Cunha ${ }^{1}$
} Thaís Martins Serra ${ }^{1}$, Raquel Machado Schincaglia ${ }^{1}$, Marina Alves Coelho Silva ${ }^{2}$ (D), Maria Aderuza Horst ${ }^{1(D)}$ Maurício Ariel Rostagno ${ }^{3}$ (D), Kelly Grace Magalhães ${ }^{4}\left(\mathbb{D}\right.$, Luiz Carlos Cunha ${ }^{2}$ and Patrícia Borges Botelho ${ }^{5, *(D)}$

check for

updates

Citation: de Oliveira, A.C.; Gomes,

A.P.O.; Rodrigues, L.C.; Cunha,

R.d.S.; Serra, T.M.; Schincaglia, R.M.; Silva, M.A.C.; Horst, M.A.; Rostagno, M.A.; Magalhães, K.G.; et al. Organic Beet Leaves and Stalk Juice

Attenuates the Glutathione

Peroxidase Increase Induced by High-Fat Meal in Dyslipidemic Patients: A Pilot Double-Blind, Randomized, Controlled Trial. Appl. Sci. 2022, 12, 1973. https://doi.org/ 10.3390/app12041973

Academic Editors: António José Madeira Nogueira and Andrea Luísa Fernandes Afonso

Received: 26 November 2021

Accepted: 9 February 2022

Published: 14 February 2022

Publisher's Note: MDPI stays neutral with regard to jurisdictional claims in published maps and institutional affiliations.

Copyright: (C) 2022 by the authors. Licensee MDPI, Basel, Switzerland. This article is an open access article distributed under the terms and conditions of the Creative Commons Attribution (CC BY) license (https:// creativecommons.org/licenses/by/ $4.0 /)$
1 College of Nutrition, Federal University of Goias, Goiânia 74605-080, Brazil; amandacris.nutri@gmail.com (A.C.d.O.); gomessanna@gmail.com (A.P.O.G.); lohcharife@gmail.com (L.C.R.); raisa_cunha@hotmail.com (R.d.S.C.); t.martinsserra@gmail.com (T.M.S.); raquelms@outlook.com (R.M.S.); aderuza@gmail.com (M.A.H.)

2 College of Pharmacy, Federal University of Goias, Goiânia 74605-170, Brazil marinalves.coelho@gmail.com (M.A.C.S.); lucacunha@gmail.com (L.C.C.)

3 College of Applied Sciences, State University of Campinas, Limeira 13484-350, Brazil; mauricio.rostagno@gmail.com

4 Laboratory of Immunology and Inflammation, University of Brasília, Brasília 70910-900, Brazil; kellymagalhaes@gmail.com

5 Department of Nutrition, College of Health Sciences, University of Brasília, Brasília 70910-900, Brazil

* Correspondence: patriciabotelho@unb.br

Featured Application: Organic beet leaves and stalks had better nutritional compositions than conventional ones. The organic beet leaves and stalk juice attenuated the increase in GPx activity in the postprandial period. The consumption of beet leaves and stalks may contribute to treatment of the conditions associated with dyslipidemia.

\begin{abstract}
The beet, including the leaves and stalk (BLS), is a vegetable with great antioxidant potential. The aim of this study was to evaluate the differences in the nutritional composition and the concentration of total phenolics between the organic and conventional BLS and to verify whether the ingestion of an organic BLS juice containing different concentrations of polyphenols modulated some biomarkers of oxidative stress after the ingestion of a high-fat meal in individuals with dyslipidemia. A controlled, randomized, double-blind, crossover clinical trial with a washout period of 1 week was carried out. A 12-h fasting blood sample was collected. Afterward, the participants consumed a high-fat meal, followed by the ingestion of a placebo or one of the organic BLS juices containing either 32.0 or $77.5 \mathrm{mg} / 100 \mathrm{~mL}$ of polyphenols. Blood samples were obtained 30, 60, 120 and $180 \mathrm{~min}$ after the first blood collection. The composition analysis showed that organic BLS had a better nutritional composition than conventional ones. The high-fat meal induced postprandial hypertriglyceridemia after $120 \mathrm{~min}(p<0.001)$ and increased the concentration of malondialdehyde after $30 \mathrm{~min}(p<0.001)$. In addition, there was a significant increase in GPx in $30 \mathrm{~min}(p=0.026)$. This increase was attenuated in the group that received the highest dose of polyphenols when compared with the placebo after 30 $\min (p=0.045)$. Therefore, the organic BLS juice containing $77.5 \mathrm{mg}$ of polyphenols was efficient at modulating one of the postprandial mechanisms of enzymatic antioxidant protection in individuals with dyslipidemia.
\end{abstract}

Keywords: antioxidants; polyphenols; postprandial period

\section{Introduction}

The postprandial state is a period of dynamic metabolism in which the transport, biosynthesis and metabolism of dietary components such as glucose, lipids and proteins 
occurs. During this period, the organism responds to short-term disturbances with adaptive mechanisms in order to restore homeostasis [1,2]. However, the consumption of highenergy meals, together with the consumption of several meals during the day, contributes to a greater formation of reactive oxygen species (ROS) or reactive nitrogen species (RNS). At this stage, the imbalance between the formation of ROS, RNS and antioxidants in favor of oxidants can potentially lead to a condition called postprandial oxidative stress [2], which can cause cellular dysfunction and biological damage.

The consumption of meals with excessive amounts of lipids, especially saturated fats, is one of the factors that contributes significantly to this acute state of imbalance by triggering a significant increase in the serum triglyceride (TG) concentration. Hypertriglyceridemia leads to the formation of smaller and more atherogenic low-density lipoproteins (LDLs). When taken from the subendothelial space, these lipoproteins boost an inflammatory process which increases the production of ROS, therefore increasing oxidative stress and, consequently, increasing the risk of cardiometabolic diseases [3].

In response to excessive ROS production, the organism has an endogenous (antioxidant enzymes) and exogenous (flavonoids, $\alpha$-tocopherol, carotenoids and vitamin $C$, among others) antioxidant system that neutralizes these reactive species by preventing free radicals from taking electrons [4]. Therefore, an adequate supply of antioxidants from meals consumed throughout the day could reduce postprandial oxidative stress [5]. In this context, red beetroot (Beta vulgaris L.) has been widely studied due to its high content of antioxidants [6]. It is a plant in which the roots, stalks and leaves are good sources of bioactive compounds, including phenolic compounds, which have already been associated with oxidative stress modulation in experimental studies [7].

Recent experimental studies showed that beet leaves and stalks could be used as adjuvant in dietary-induced obesity in mice to reduce the damage generated by oxidative stress and to improve parameters related to glucose homeostasis, including fasting glucose and glucose tolerance $[8,9]$. Beyond that, vitexin and its derivatives were the major bioactive compounds present in beet leaves and stalks. It has a wide range of pharmacologic effects, including antioxidant, anti-cancer, anti-inflammatory and neuroprotective effects [9,10].

However, to date, no studies have reported the effects of beet leaves and stalks on oxidative stress in humans. In addition, the polyphenol content of the beet can vary according to conventional or organic cultivation [11,12], and there is evidence that the antioxidants present in leaves and stalks of beets overlap that of the root, a fact that should be considered to encourage the use of alternative edible parts of food, reducing food waste $[7,13]$.

Therefore, the aim of this study was to evaluate the differences in the nutritional composition and the concentration of total phenolics between organic and conventional beet leaves and stalks. From these results, we then verified whether the ingestion of beet leaves and stalk juice with different concentrations of polyphenols could modulate some oxidative stress markers and an inflammatory marker after consuming a high-fat meal in individuals with dyslipidemia.

\section{Materials and Methods}

\subsection{Beet Leaves and Stalks: Organic vs. Conventional}

\subsubsection{Sample Collection and Pre-Preparation}

The samples of organic beet (Beta vulgaris) leaves and stalks were obtained from a farm in the city of Goianápolis, Goiás, Brazil (tropical climate; altitude: $995 \mathrm{~m}$ ). Conventional samples were collected in Anápolis, Goiás (tropical climate; altitude: $1005 \mathrm{~m}$ ). All analyses were performed at the Federal University of Goiás (UFG) in the city of Goiânia at the Food Analysis Laboratory (LANAL) of the College of Nutrition (FANUT).

Both conventional and organic beet leaves and stalks were harvested on the same day in the morning between 8:00 a.m. and 10:00 a.m. They were then packed in plastic bags and transported to the place of analysis in thermal boxes. All steps were carried out with great care in order to avoid physical damage and, consequently, loss of nutrients in the samples. 
To prepare the samples, the leaves and stalks were cleaned with running water, removing the excess soil. Subsequently, they were immersed in a solution with $10 \mathrm{~mL}$ of active chlorine $2.5 \%$ added to $1 \mathrm{~L}$ of water for $10 \mathrm{~min}$ and then rinsed with running water. Then, they were lightly dried with a non-recycled paper towel. The leaves were manually separated from the stalks, placed separately in specific trays and stored in an ultra-freezer (WICTORY) at $-40^{\circ} \mathrm{C}$ for about $1 \mathrm{~h}$.

Once frozen, they were lyophilized (LIOTOP, model L108) for $28 \mathrm{~h}$. Then, they were homogenized in a processor (IKa brand, model: A11 basic), forming a powder, vacuum packed and stored in the freezer (brand: electrolux model: F250) at $-20{ }^{\circ} \mathrm{C}$ until analysis. At the end of these processes, four dry samples were obtained: organic leaves, organic stalks, conventional leaves and conventional stalks.

\subsubsection{Nutritional Composition}

The humidity content was determined in two moments: with the samples just sanitized and after passing through lyophilization. For this analysis, the recommendations of the Institute Adolfo Lutz (1985) [14] were followed. Initially, the Petri dishes were placed in the oven (Tecnal TE $393 \mathrm{I}$ ) at $105^{\circ} \mathrm{C}$ for $1 \mathrm{~h}$ to eliminate any interference due to humidity. Then, $5 \mathrm{~g}$ of each type of sample were weighed in triplicate in the Petri dishes and stored in an oven for $5 \mathrm{~h}$ at $105^{\circ} \mathrm{C}$. The samples were then removed from the oven and placed in a desiccator to cool until reaching room temperature. Then, weighing was performed, repeating the heating and cooling procedure every hour until a constant weight was obtained for the samples.

The ash content was also determined according to the methodology described by Instituto Adolfo Lutz (1985) [14] through incineration in a muffle. Then, $5 \mathrm{~g}$ of each type of sample was also weighed in triplicate and placed in a porcelain crucible, properly identified by numbering and previously heated in a muffle (EDG $10 \mathrm{P}$ ) at $550^{\circ} \mathrm{C}$ for $5 \mathrm{~h}$, cooled in a desiccator until reaching room temperature and weighed. Incineration in a muffle and cooling was repeated every hour until reaching a constant weight.

For protein determination, we used the Kjeldahl method (1883) [15] with modifications according to the AOAC (1984) [16]. First, $0.150 \mathrm{~g}$ of each sample was weighed in triplicate and placed in digestion tubes. Then, $1 \mathrm{~g}$ of a catalyst mixture (titanium dioxide $\left(\mathrm{TIO}_{2}\right)$, copper sulphate $\left(\mathrm{CuSO}_{4}\right)$ and potassium sulphate $\left(\mathrm{K}_{2} \mathrm{SO}_{4}\right)$ in the proportion of 0.3:0.3:10.0) and $5 \mathrm{~mL}$ of $\mathrm{H}_{2} \mathrm{SO}_{4}$ were added to each tube, and these were taken to the digester block (Tecnal TE-040/25), starting the digestion at $50{ }^{\circ} \mathrm{C}$ and progressing until reaching $350{ }^{\circ} \mathrm{C}$ to avoid the formation of scum. The complete digestion of the sample took approximately 3 days until the inner walls of the tubes were completely clean, the white smoke of the $\mathrm{SO}_{2}$ (sulfur dioxide) decreased considerably or practically disappeared, and the liquid inside the tubes was emerald green-colored.

After digestion, the tubes were cooled in a sandbox until reaching room temperature. Then, one by one, they were placed in the distillation apparatus with the tip of the condenser dipped into a 250-mL Erlenmeyer flask containing $10 \mathrm{~mL}$ of $\mathrm{H}_{3} \mathrm{BO}_{3}$ solution and 3 drops of Andersen's indicator. During distillation, a $50 \% \mathrm{NaOH}$ solution was added to the tube containing the sample, forming a dark brown precipitate of cupric oxide $(\mathrm{CuO})$. Distillation continued until $100 \mathrm{~mL}$ was obtained in the Erlenmeyer flask.

After distillation, each Erlenmeyer flask containing the solution resulting from the distillation of each tube was titrated with a $0.01-\mathrm{N} \mathrm{HCl}$ solution. To calculate the protein value, the following formula was used: \% Protein $=($ Volume $\mathrm{HCl} \times 0.01 \times 6.25 \times 0.014 \times 10) /$ mass of sample (g).

For determination of the total lipids, the method of Bligh and Dyer (1959) [17] was used. Approximately $2 \mathrm{~g}$ of each sample was weighed in triplicate into $70-\mathrm{mL}$ tubes. Then, $10 \mathrm{~mL}$ of chloroform, $20 \mathrm{~mL}$ of methanol and $8 \mathrm{~mL}$ of distilled water were added to each tube. The tubes were then sealed with thread sealant to prevent any overflow of the liquid and placed in a rotary homogenizer (Electrocraft) for $30 \mathrm{~min}$. After cooling, another $10 \mathrm{~mL}$ 
of chloroform and $10 \mathrm{~mL}$ of $1.5 \%$ sodium sulfate solution were added to each of the tubes, which were capped again with a screw sealer and shaken for $2 \mathrm{~min}$.

Then, the tubes were left to rest to separate the layers naturally. After clear separation, the upper methanolic layer was sucked off and discarded. Using filter paper, the lower layer was filtered into an Erlenmeyer flask, $5 \mathrm{~mL}$ of each filtrate was transferred to a petri dish (previously tared) using a graduated pipette and taken to the hood for evaporation of all the solvent. Then, they were cooled to room temperature in a desiccator and weighed. To calculate the total lipid content, the following formula was used: $\%$ lipid = (weight lipid $(\mathrm{g}) \times 4 \times 100$ )/weight of sample $(\mathrm{g})$. For determination of the total carbohydrates, the ash, proteins, lipids and moisture of each sample were added together and subtracted from 100.

\subsubsection{Total Phenolics}

The determination of the total phenolics followed the Folin-Ciocalteu method described by Singleton, Orthofer and Lamuela (1999) [18] with modifications. For the extraction of phenolics, $0.5 \mathrm{~g}$ of each type of sample was weighed, and $10 \mathrm{~mL}$ of $50 \%$ ethanol was added. After stirring for $5 \mathrm{~min}$ for homogenization, they were kept for $10 \mathrm{~min}$ in an ultrasound and centrifuged (Hitachi ${ }^{\circledR}, \mathrm{CF} 16-\mathrm{RN}$ Series, Chiyoda City, Tokyo) at $1008 \times g$ for $10 \mathrm{~min}$. Then, the supernatant from each sample was collected and pipetted into a $25-\mathrm{mL}$ flask. A second extraction was performed following the same process, and the supernatant was pipetted into the same flask together with the first extract. The volumetric flask was completed with the $50 \%$ ethanol solution, and after homogenization, the extracts were stored in a refrigerator (Eletrolux R28) for readings in less than $24 \mathrm{~h}$.

To determine the concentration of the total phenolics in the extract, an aliquot of $0.25 \mathrm{~mL}$ of each of the 12 extracts obtained (triplicate of each sample) was transferred to an amber tube, and then $2.75 \mathrm{~mL}$ of $3 \%$ Folin-Ciocalteu solution was added. For the blank, two tubes containing $0.25 \mathrm{~mL}$ of $50 \%$ ethanol were made, and $2.75 \mathrm{~mL}$ of $3 \%$ Folin-Ciocalteu solution was added. The tubes were kept for $5 \mathrm{~min}$ in the dark at rest, and then $0.25 \mathrm{~mL}$ of $10 \%$ sodium carbonate $\left(\mathrm{Na}_{2} \mathrm{CO}_{3}\right)$ solution was added. They were then homogenized and left to rest in the dark for $60 \mathrm{~min}$ at room temperature.

The reading of the absorbances of the samples was carried out in a SpectraManeger spectrophotometer at a wavelength of $765 \mathrm{~nm}$. The content of the total phenolics was determined by interpolating the absorbance of the samples with the calibration curve previously performed $(20-300 \mathrm{mg} / \mathrm{L})$, and the results were expressed in gallic acid equivalents (GAE, $\mathrm{mg} / 100 \mathrm{~g}$ of sample).

\subsection{Clinical Trial}

\subsubsection{Preparation of the Juice for the Clinical Trial}

The organic beet leaves and stalks were obtained weekly from an organic food market in the city of Goiânia, Goiás, Brazil (IBD certificate CA14623/20, operator code GO019) and then were sanitized and stored at $4{ }^{\circ} \mathrm{C}$ in plastic bags identified with a date and a concentration of phenolic compounds. The total phenolic content was analyzed by the Folin-Ciocalteu method [18]. Every week, the BLS quantities were readjusted according to the amount of polyphenols in that batch. Moreover, to ensure that all participants received the same amount of polyphenols, previous tests were performed to evaluate the maintenance of the amount of polyphenols in the BLS stored in a refrigerator during the week. In general, approximately $45 \mathrm{~g}$ and $101.1 \mathrm{~g}$ of beet leaves and stalks were used to prepare the juice for doses 1 (low dose) and 2 (high dose), in order to obtain a final concentration of $32 \mathrm{mg}$ of polyphenols $/ 100 \mathrm{~mL}$ and $77.5 \mathrm{mg}$ of polyphenols/100 mL, respectively. The juices were prepared immediately before consumption by a researcher not involved in the study, considering the quantities calculated for that batch of beet leaves and stalks with $100 \mathrm{~mL}$ of mineral water. Afterward, they were strained into extra-fine twill mesh stainless steel conical strainers and stored at $4{ }^{\circ} \mathrm{C}$ in a black capped cup identified with the date, name of the volunteer and code of the group until consumption. 
To characterize the juice, the quantification of vitexin-2-O-rhamnoside (VR; MW 578) and vitexin derivatives as well as the antioxidant capacity by the oxygen radical absorbance capacity (ORAC) was performed as described previously by us in Gomes et al., (2019) [19].

\subsubsection{Recruitment}

Volunteers were recruited by advertising the project on social networks and on the premises of the Federal University of Goiás (UFG). The following inclusion criteria were used: having a diagnosis of dyslipidemia and being 20-59 years of age. To confirm the diagnosis of dyslipidemia, a lipidogram was performed, and the values obtained were classified according to the recommendations of the Brazilian Society of Cardiology [20].

The individuals who used insulin, had diabetes, kidney disease, liver disease or thyroid disorders, were undergoing weight control treatment, used antihypertensives or antilipemiantes, had any cardiovascular event in the past 6 months, were pregnant and breastfeeding women, menopausal women or women on hormone replacement were excluded.

This study was performed in accordance with the principles recommended in the Declaration of Helsinki. The main project of this study was submitted to the Research Ethics Committee Involving Human Beings at the Federal University of Goiás (UFG) (692.586, CAAE 30274214.0.0000.5083). The clinical trial was also registered in the Brazilian Registry of Clinical Trials (ReBEC) (RBR-59bm68).

\subsubsection{Study Design}

The clinical trial was a randomized, placebo-controlled, double-blind crossover with 13 individuals with dyslipidemia. The trial consisted of three stages with a washout period of 1 week. At the end of the study, all volunteers received all treatments, and thus, each group was composed of 13 individuals. Using the R (sample) function of the R statistical software, the volunteers were initially randomly assigned to three experimental groups by an independent statistician: the control group, which received water plus flavoring (rum essence), the low dose group, which received the beet leaves and stalk juice containing $32 \mathrm{mg}$ of polyphenols $(319.67 \mathrm{mg} / \mathrm{L})$ and the high dose group, which received the beet leaves and stalk juice containing $77.5 \mathrm{mg}$ of polyphenols $(775.2 \mathrm{mg} / \mathrm{L})$. As there were no studies carried out in humans using beet leaves and stalks, the concentrations were based on the number of leaves that was considered viable for daily human consumption. Amounts higher than those used conferred difficulty in preparation and an unpleasant taste.

The protocol followed the same pattern at each stage and was previously described by Gomes et al., (2019) [19]. The individuals were instructed not to perform vigorous physical exercises $24 \mathrm{~h}$ before the data collection, not to drink alcohol or eat foods rich in polyphenols $72 \mathrm{~h}$ before. To guarantee that, a list containing antioxidant-rich food was provided, and possible alterations in dietary intake were monitored by 24 -h recall throughout the clinical trial.

First, blood was collected from the peripheral vein after a 12-h fast (T0). Then, the volunteers received a breakfast containing a pastry filled with pepperoni sausage, bacon and cheddar cheese accompanied by an industrialized coconut candy (conventional condensed milk and coconut). The meal had a total energy content of $720.6 \mathrm{kcal}$, with $38.5 \mathrm{~g}(21 \%)$ of carbohydrates, $19.7 \mathrm{~g} \mathrm{(11 \% )}$ of protein and $54.2 \mathrm{~g}(68 \%)$ of total fats, including $17.7 \mathrm{~g}$ of saturated fat. The volunteers were instructed to eat the entire meal within a maximum period of $15 \mathrm{~min}$.

Five min after the end of the meal, flavored water with rum essence (without phenolic compounds) or beet leaves and stalk juice was provided in a black disposable cup, capped and encoded. The black cups had the same appearance for all groups and were distributed by a researcher not involved in the study. Thus, the volunteers and staff were blinded.

Then, new blood samples were taken at times of 30 (T30), 60 (T60), 120 (T120) and 180 (T180) min after the first blood collection. The blood samples were immediately processed in 
a refrigerated centrifuge $\left(\right.$ Hitachi $^{\circledR}, \mathrm{CF} 16-\mathrm{RN}$ Series) at $117 \times \mathrm{g}$ for $15 \mathrm{~min}$ for the separation of plasma and erythrocytes, which were lysed with a buffer containing $0.32 \mathrm{M}$ sucrose, $10 \mathrm{mM}$ Tris- $\mathrm{HCl}$ buffer (pH 7.4), $5 \mathrm{mM} \mathrm{MgCl} 2$ and $1 \%$ Triton X-100 according to the protocol of Adzic et al., (2006) [21] and stored in an ultra-freezer at $-80{ }^{\circ} \mathrm{C}$ until the moment of the analyses. The following biomarkers were analyzed: triglycerides, total polyphenols, malondialdehyde, TNF $\alpha$ and the activity of catalase and glutathione peroxidase.

Anthropometric assessment of the participants was performed during screening. The weight, height and waist circumference were collected according to the work of Heyward and Stolarczyc (2000) [22] by using a digital anthropometric scale (Filizola, Brazil) and an inextensible and inelastic millimeter tape. The percentage of body fat was assessed at the last week of data collection by dual-energy X-ray absorptiometry (DXA) (in DPX NT, GE model equipment) to characterize the studied population.

\subsubsection{Determination of the Phenolic Compound Concentration in Plasma}

The extraction of phenolic compounds was carried out according to Serafini and Ferro Luzi (1998) [23]. First, $400 \mu \mathrm{L}$ of hydrochloric acid solution $(1 \mathrm{M})$ was added to $200 \mu \mathrm{L}$ of plasma, followed by vortexing for $1 \mathrm{~min}$. Then, the sample was incubated in a water bath at $37^{\circ} \mathrm{C}$ for $30 \mathrm{~min}$, followed by the addition of $400 \mu \mathrm{L}$ of sodium hydroxide in $75 \%$ methanol (2 M). Afterward, the sample was incubated again in the same conditions for another $30 \mathrm{~min}$, and at the end, $400 \mu \mathrm{L}$ of metaphosphoric acid was added.

The sample was then vortexed for $2 \mathrm{~min}$ and centrifuged at $29 \times g$ at $4{ }^{\circ} \mathrm{C}$ for $10 \mathrm{~min}$. The supernatant was collected and stored in a previously identified Eppendorf tube. Another extraction was performed by adding water and acetone (1:1), followed by centrifugation (Hitachi ${ }^{\circledR}, \mathrm{CF} 16-\mathrm{RN}$ Series) at $29 \times \mathrm{g}$ at $4{ }^{\circ} \mathrm{C}$ for $5 \mathrm{~min}$. After this procedure, the two supernatants were combined and centrifuged again at $29 \times g$ at $4{ }^{\circ} \mathrm{C}$ for $5 \mathrm{~min}$. Then, the final supernatant was used to quantify the content of polyphenols according to the Folin-Ciocalteu method described by Singleton and Rossi (1999) [18] with modifications. Briefly, $250 \mu \mathrm{L}$ of the supernatant or methanol (white) and $2.75 \mathrm{~mL}$ of $3 \%$ Folin-Ciocalteu were added to an amber test tube, followed by vortexing for $10 \mathrm{~s}$ and then followed by incubation in a dark environment for $5 \mathrm{~min}$ at room temperature. Afterward, $250 \mu \mathrm{L}$ of $10 \%$ sodium carbonate solution was added, followed again by vortexing and incubation in the dark for $60 \mathrm{~min}$. After that, the absorbance of the samples was analyzed in triplicate using the Expecta Manager spectrophotometer (Fullerton, CA, USA) at a wavelength of $765 \mathrm{~nm}$. The total phenolic content was obtained by interpolating the absorbance of the samples compared to the calibration curve, which used gallic acid (GA) as the standard solution (20-200 mg/L), so that the results were expressed in mg of equivalent of GA per gram of sample (GAE/g).

\subsubsection{Determination of Malondialdehyde (MDA) Concentration in Plasma}

The plasma MDA concentration was determined from separation by high-performance liquid chromatography (HPLC), according to the work of Antunes et al. (2008) [24] with modifications. First, $50 \mu \mathrm{L}$ of plasma was added to $100 \mu \mathrm{L}$ of sodium hydroxide solution $(1.5 \mathrm{M})$ and incubated in a water bath for $30 \mathrm{~min}$ at $60^{\circ} \mathrm{C}$ for sample hydrolysis. After this period, $100 \mu \mathrm{L}$ of $20 \%$ perchloric acid solution was added and homogenized in a vortex mixer for $30 \mathrm{~s}$, and then the solution was placed in a refrigerated microcentrifuge (Hitachi ${ }^{\circledR}$, CF16-RN Series) at $4{ }^{\circ} \mathrm{C}$ for $10 \mathrm{~min}$ at $2119 \times g$ for protein precipitation. To the vials were added $25 \mu \mathrm{L}$ of 2.4 dinitrophenylhydrazine (DNPH) solution $(5 \mathrm{mM})$ in the inserts and, subsequently, $200 \mu \mathrm{L}$ of the supernatant. Then, the sample was kept protected from light for $30 \mathrm{~min}$ to allow the derivatization reaction to occur.

Chromatographic analysis was performed using the HPLC equipment with PDA detector (HPLC-PDA), a Shimadzu Prominence ${ }^{\circledR}$ model 20AT with a C18 ACE ${ }^{\circledR}$ column $(150 \times 4.0 \mathrm{~mm}$ DI, $5 \mu \mathrm{m})$ submitted to a temperature of $30^{\circ} \mathrm{C}$ with a mobile phase flow of $1 \mathrm{~mL} / \mathrm{min}$ (water acidified with acetic acid $0.2 \%$ and acetonitrile 62:38 Merck $^{\circledR}$ —Darmstat, Germany) and an injection volume $80 \mu \mathrm{L}$ under $310 \mathrm{~nm}$. 
The calibration curve $(0.1-10 \mu \mathrm{M})$ was made by adding the standard $1,1,3,3$ tetrahydroxypropane and DNPH (Sigma ${ }^{\circledR}$ Chemical Company, St. Louis, MO, USA) to $5 \%$ albumin (substitute matrix). Albumin was used as a substitute matrix because it had negligible amounts of the analyte, whereas the plasma was not exempt from it. Quality controls were also prepared, with CQL (low): $0.25 \mu \mathrm{M}$; CQA (average): $5.0 \mu \mathrm{M}$; and CQH (high): $8.0 \mu \mathrm{M}$.

\subsubsection{Determination of Enzyme Activity (Primary Outcome)}

The catalase activity (CAT) was determined according to the work of Aebi (1994) [25] with modifications. In a test tube, $1400 \mu \mathrm{L}$ of phosphate buffer $(50 \mathrm{mM})$ and $200 \mu \mathrm{L}$ of hemolysate (1:500) were homogenized. Subsequently, $400 \mu \mathrm{L}$ of $\mathrm{H}_{2} \mathrm{O}_{2}(55 \mathrm{mM})$ were added, followed by the absorbance reading at room temperature in a Power Wave HT, Bio Teck ${ }^{\circledR}$ spectrophotometer (Winooski, VT, USA) for $15 \mathrm{~s}$ at $240 \mathrm{~nm}$. The calculations performed following the respective formula: $(2.3 / \Delta t) \cdot(a \cdot b / \Sigma c \cdot d) \cdot(\log a 1 / a 2)$, where $\Delta t$ is the variation in reaction time ( $15 \mathrm{~s}), a$ is the volume of hemolysate in the microplate, $b$ is the dilution factor of the hemolysate, $\sum$ is the molar extinction coefficient of $\mathrm{H}_{2} \mathrm{O}_{2}\left(0.071 \mathrm{M}^{-1} \mathrm{~cm}^{-1}\right), \underline{c}$ is the hemoglobin concentration of the sample in $\mathrm{g} / \mathrm{dL}, d$ is the optical pathlength in the microplate $(0.6 \mathrm{~cm}), a 1$ is the absorbance value at time zero $(t=0)$ and $a 2$ is the absorbance value at the end time $(t=15 \mathrm{~s})$. The final unit is expressed in $\mathrm{k} / \mathrm{gHb} / \mathrm{s}$.

The determination of glutathione peroxidase (GPx) activity was performed according to the Flohé and Gunzle (1984) method [26] with modifications, and the solutions were added in the following order: $135 \mu \mathrm{L}$ of phosphate buffer and EDTA $(1 \mathrm{mM})(\mathrm{pH} 7.0)$, $5 \mu \mathrm{L}$ of GSH, $5 \mu \mathrm{L}$ of GR and $20 \mu \mathrm{L}$ of diluted sample (1:200). They were then incubated in a water bath for $5 \mathrm{~min}$ at $37^{\circ} \mathrm{C}$. Sequentially, $5 \mu \mathrm{L}$ of tert-butyl hydroperoxide $(0.46 \%$ $v / v)$ and $30 \mu \mathrm{L}$ of NADPH were added. The reading was performed for 5 min at $340 \mathrm{~nm}$ and $37^{\circ} \mathrm{C}$ in a Power Wave HT Bio Teck ${ }^{\circledR}$ spectrophotometer (Winooski, VT, USA). The GPx activity was obtained by the formula $k \cdot\left(a \cdot b / \sum c \cdot d\right)$, where $k$ is the angular coefficient of the decay line $K=$ abs. Final-Abs. Inicial $/ 5 \mathrm{~min}), \underline{a}$ is the volume of hemolysate in the microplate, $\underline{b}$ is the hemolysate dilution factor, $\sum$ is the molar extinction coefficient of NADPH $\left(6.22 \times 10^{-3} \mu \mathrm{M}^{-1} \cdot \mathrm{cm}^{-1}\right), \underline{c}$ is the hemoglobin concentration of the sample in $\mathrm{g} / \mathrm{dL}$ and $\underline{d}$ is the optical path in the microplate $(0.6 \mathrm{~cm})$. The final unit is expressed in $\mathrm{nmol} \cdot \mathrm{min}^{-1} \cdot \mathrm{g} \cdot \mathrm{Hb}^{-1}$.

\subsubsection{Determination of Tumor Necrosis Factor $\alpha$ (TNF- $\alpha$ ) Concentration}

Serum tumor necrosis factor $\alpha(\mathrm{TNF} \alpha)$ was analyzed by an enzyme-linked immunosorbent assay (ELISA) using commercial kits (eBioscience and R\&D System). The test was performed following the manufacturer's instructions. Briefly, 96-well microplates were sensitized with monoclonal anti-TNF $\alpha$ antibodies diluted in PBS and incubated for $18 \mathrm{~h}$ at room temperature. The plates were blocked with $5 \%$ fetal bovine serum in PBS and incubated for $1 \mathrm{~h}$ at room temperature. Then, after a cycle of three washes with $0.05 \%$ Tween-20 solution in a PBS buffer, the plasma samples $(50 \mu \mathrm{L})$ and the serial dilutions of the standard curve were added. The plates were incubated for $1 \mathrm{~h}$ at room temperature, and after this incubation period, the respective anti-TNF $\alpha$ antibodies conjugated to biotin were added to the plates and incubated for $1 \mathrm{~h}$ at room temperature. Then, after a cycle of three washes, streptoavidin peroxidase was added, and the plates were incubated for $20 \mathrm{~min}$ at room temperature. After new washes, 3,3',5,5'-Tetramethylbenzidine substrate was added to the plates, and the reaction was stopped by adding a sulfuric acid solution $(1 \mathrm{M})$. The reaction absorbance was measured by spectrophotometry at a wavelength of $450 \mathrm{~nm}$.

\subsubsection{Statistical Analyses}

The analyses were carried out considering the variations in time points of 30,60, 120 and $180 \mathrm{~min}$ in relation to the baseline. All data were presented as the mean and standard error of the mean. 
Normality analysis was performed using the Shapiro-Wilk test, and the carryover effect was analyzed as elucidated by Rosner (2011) [27]. We considered as outliers the values that were below or above the interquartile range multiplied by 1.5 [27]. Outliers were excluded from the statistical analysis, and a factorial ANOVA test was used to compare the means between intervention groups, as well as a Student's $t$ test to verify the effectiveness of inducing hypertriglyceridemia and oxidative stress in relation to the baseline. $R^{\circledR}$ version 3.1.2 and R Studio ${ }^{\circledR}$ software were used, and the significance level adopted was $5 \%$.

The post hoc sample size calculation considered an effect size of 12.26 (obtained from the data of significant variation of GPx activity at the moment of $30 \mathrm{~min}$ ), an absolute error (alpha) of 5\% and a sample size of 13 individuals per stage of intervention and resulted in a test power (1-beta) of $99 \%$, which made the sample adequate for the present analyses. $\mathrm{G}^{*}$ Power software was used to this calculation.

\section{Results}

\subsection{Beet Leaves and Stalks: Organic vs. Conventional}

Regarding the composition of macronutrients, the organic leaves had a higher concentration of lipids and proteins and a lower content of carbohydrates when compared with conventional leaves. However, no difference in the polyphenol concentrations was observed (Table 1). In contrast, the organic stalks showed a higher concentration of proteins, carbohydrates and polyphenols and lower lipids when compared with the conventional stalks (Table 2). In addition, the organic and conventional leaves showed higher concentrations of polyphenols than those presented by both organic and conventional stalks.

Table 1. Nutritional composition of organic and conventional leaves.

\begin{tabular}{cccc}
\hline Nutrients & Organic Leaf & Conventional Leaf & $p$ \\
\hline Moisture $(\%)$ & $91.09 \pm 0.66$ & $89.68 \pm 0.46$ & 0.038 \\
Ash $(\mathrm{g} / 100 \mathrm{~g})$ & $2.20 \pm 0.04$ & $2.23 \pm 0.02$ & 0.411 \\
CHO $(\mathrm{g} / 100 \mathrm{~g})$ & $1.85 \pm 0.62$ & $3.54 \pm 0.40$ & 0.016 \\
LIP $(\mathrm{g} / 100 \mathrm{~g})$ & $1.06 \pm 0.00$ & $0.98 \pm 0.00$ & 0.000 \\
PTN $(\mathrm{g} / 100 \mathrm{~g})$ & $3.80 \pm 0.00$ & $3.58 \pm 0.12$ & 0.035 \\
Total phenolics & $89.20 \pm 9.78$ & $95.75 \pm 0.69$ & 0.366 \\
$(\mathrm{mg} / 100 \mathrm{~g})$ & & & \\
\hline
\end{tabular}

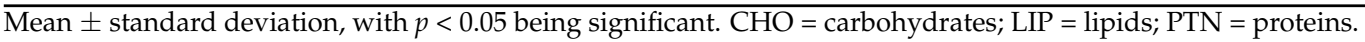

Table 2. Nutritional composition of organic and conventional stalks.

\begin{tabular}{cccc}
\hline Nutrients & Organic Stalks & Conventional Stalks & $p$ \\
\hline Moisture $(\%)$ & $94.22 \pm 0.88$ & $96.31 \pm 0.24$ & 0.017 \\
Ash $(\mathrm{g} / 100 \mathrm{~g})$ & $1.28 \pm 0.42$ & $0.92 \pm 0.00$ & 0.000 \\
CHO $(\mathrm{g} / 100 \mathrm{~g})$ & $3.18 \pm 0.90$ & $1.68 \pm 0.24$ & 0.049 \\
$\mathrm{LIP}(\mathrm{g} / 100 \mathrm{~g})$ & $0.17 \pm 0.00$ & $0.31 \pm 0.00$ & 0.001 \\
PTN $(\mathrm{g} / 100 \mathrm{~g})$ & $1.14 \pm 0.00$ & $0.77 \pm 0.02$ & 0.000 \\
Total phenolics & $41.13 \pm 0.55$ & $27.84 \pm 0.85$ & 0.000 \\
(mg/100 g) & & \\
\hline Mean \pm standard deviation, with $p<0.05$ being significant. CHO = carbohydrates; LIP = lipids; PTN = proteins.
\end{tabular}

\subsection{Characterization of Organic BLS Juice Phenolic Profile}

One of the major compounds found in the BLS juice was vitexin-2-O-rhamnoside. The representative chromatogram of polyphenols present in BLS juice can be found in the work of Gomes et al. (2019) [19]. A higher antioxidant capacity was observed in the high-dose juice (12.15 \pm 1.79 vs. $5.93 \pm 0.78 \mathrm{mM}$ Eq.trolox/g).

\subsection{Population Characterization}

In total, 91 participants were screened, 47 agreed to participate in the research, and 25 were selected according to the eligibility criteria. During the clinical trial, 10 participants 
were removed from the study, with 1 due to a surgical procedure, 6 for difficulties in blood collection and 3 for other personal reasons. In addition, two were excluded from the statistical analysis (outliers) (Figure 1). In total, 13 participants completed the study. The participants' characteristics at baseline are shown in Table 3. The carryover analysis did not indicate any associations between treatments $(p \geq 0.05)$, confirming that the washout time was adequate.

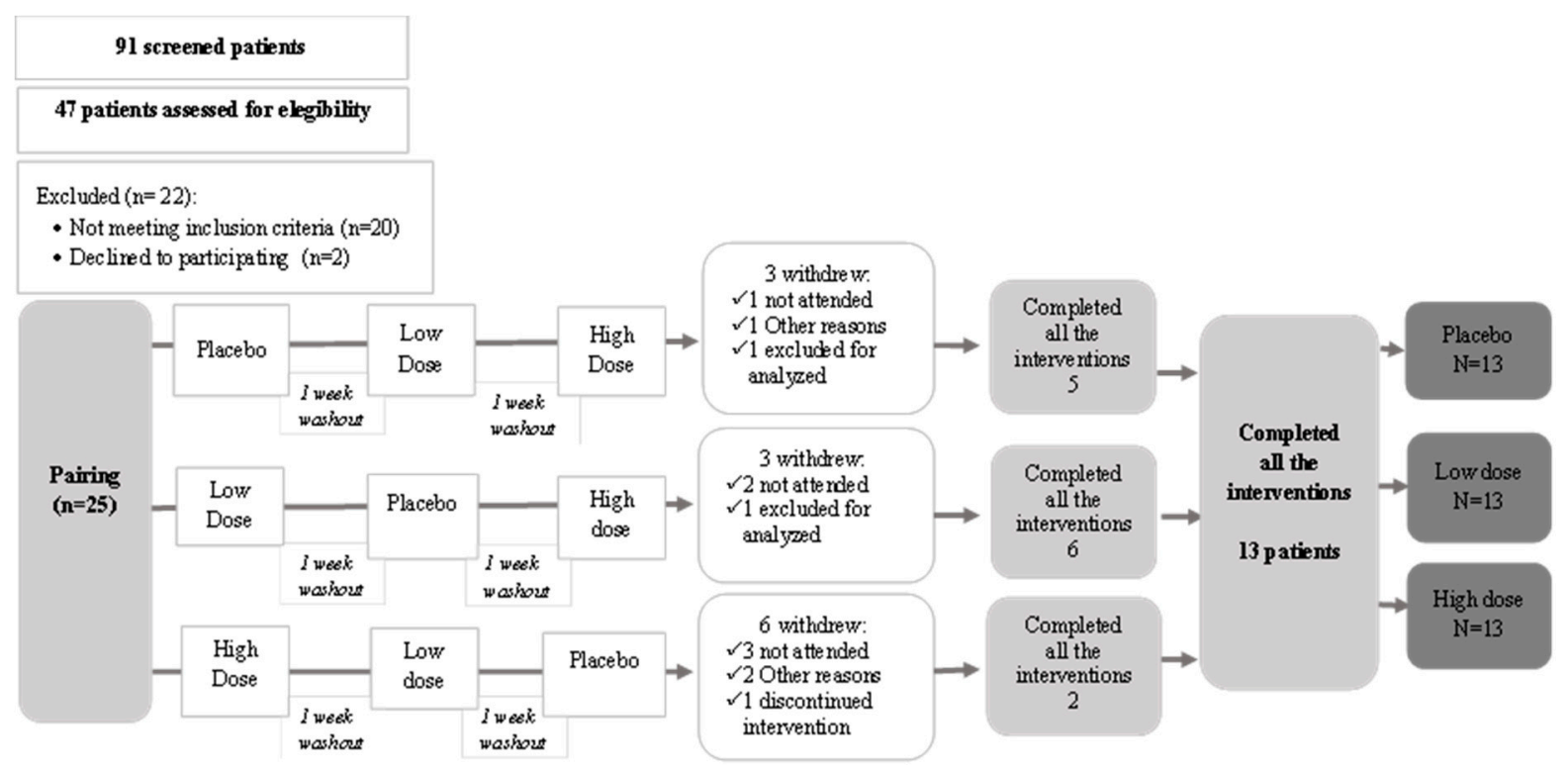

Figure 1. Flowchart of patients during intervention. Data adapted from Gomes et al. [19].

Table 3. Participants' characteristics at the baseline $(n=13)$.

\begin{tabular}{cc}
\hline Variables & Means (Standard Error) \\
\hline Age $(\mathrm{y})$ & $40.6(2.3)$ \\
Body mass index $\left(\mathrm{kg} / \mathrm{m}^{2}\right)$ & $32.7(1.5)$ \\
Waist circumference $(\mathrm{cm})$ & $96.8(3.1)$ \\
Body fat $(\%)$ & $46.2(2.2)$ \\
Total cholesterol $(\mathrm{mg} / \mathrm{dl})$ & $211.0(9.8)$ \\
HDL cholesterol $(\mathrm{mg} / \mathrm{dL})$ & $47.1(3.3)$ \\
LDL cholesterol $(\mathrm{mg} / \mathrm{dL})$ & $126.5(8.8)$ \\
VLDL cholesterol $(\mathrm{mg} / \mathrm{dL})$ & $37.4(2.9)$ \\
Triacylglycerol $(\mathrm{mg} / \mathrm{dL})$ & $187.0(14.6)$ \\
\hline
\end{tabular}

Values are expressed as means and standard error of the mean. HDL = high-density lipoprotein; LDL = low-density lipoprotein; VLDL = very low-density lipoprotein. Data adapted from Gomes et al. [19].

\subsection{Induction of Hypertriglyceridemia and Lipid Peroxidation}

The hyperlipidic diet induced hypertriglyceridemia after $120 \mathrm{~min}$ and $180 \mathrm{~min}(p<0.001$ for both) and postprandial lipid peroxidation, measured by the MDA concentration, after $30 \mathrm{~min}, 60 \mathrm{~min}, 20 \mathrm{~min}$ and $180 \mathrm{~min}$ from the first blood collection $(p<0.05$ for all of them) (Figure 2a,b). In addition, there was a significant increase in GPx in $30 \mathrm{~min}(p=0.026)$ (Figure 2c). 


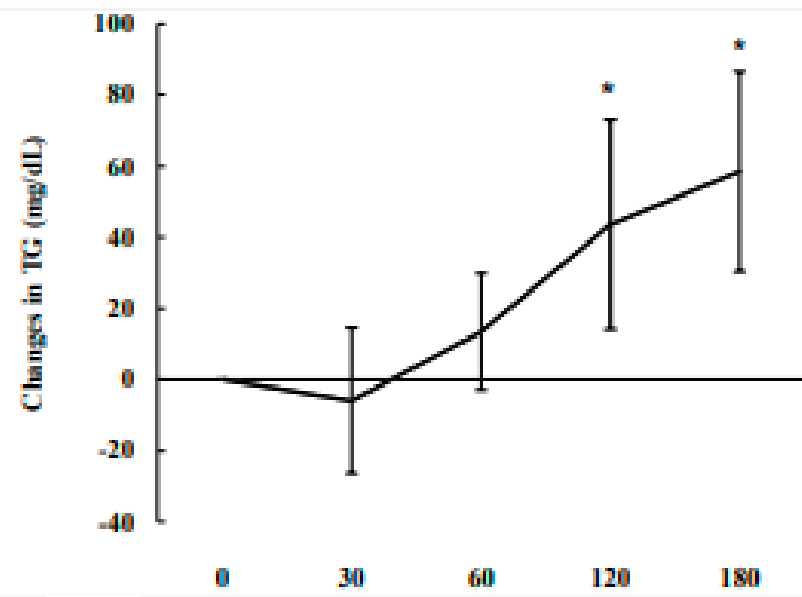

(a)
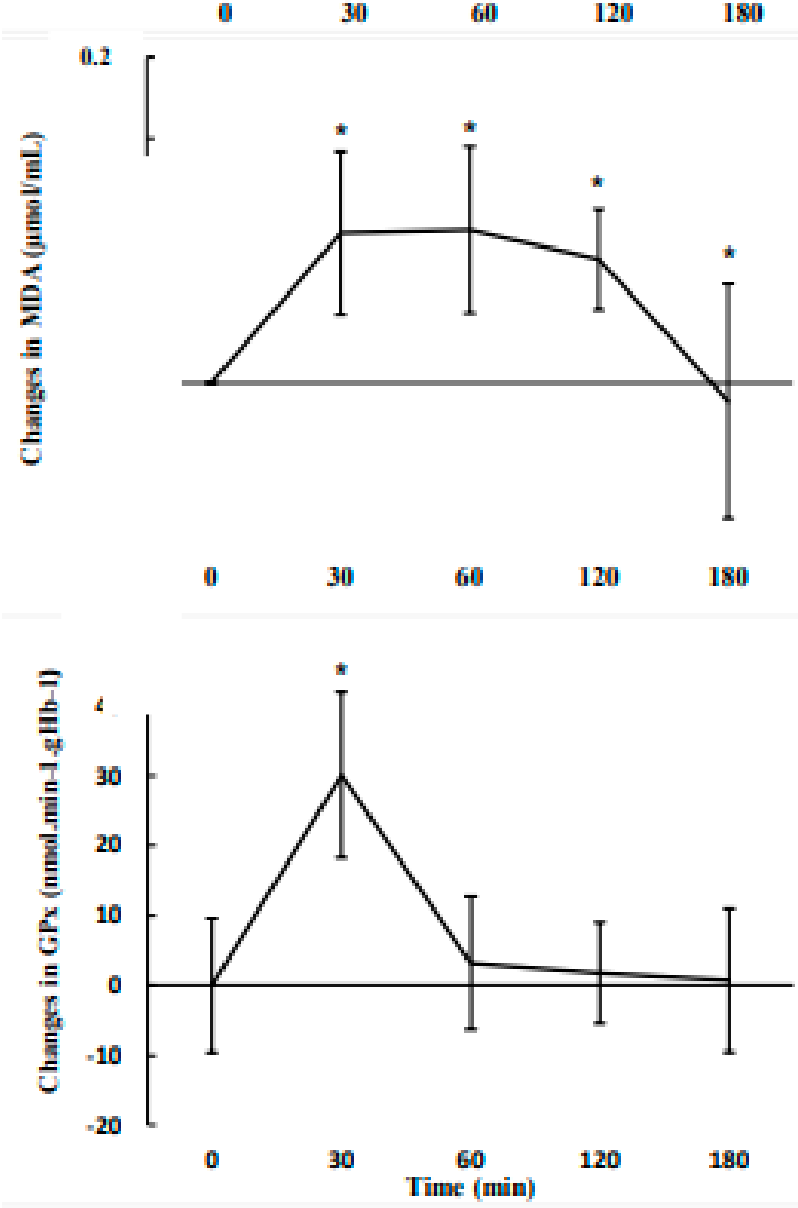

(c)

Figure 2. Induction of hypertriglyceridemia (a) and oxidative stress assessed by lipid peroxidation (b) and GPx activity (c) at time points 30, 60, 120 and $180 \mathrm{~min}$ in individuals with dyslipidemia, where $\mathrm{n}=13$. The asterisk $\left.{ }^{*}\right)$ indicates significant differences from the Student's $t$ test for a sample in relation to a reference value (baseline) with Bonferroni correction and $p<0.001$. Values are expressed as the mean and standard error of the mean, represented by the error bars. TG = triglycerides; MDA $=$ malondialdehyde; GPx = glutathione peroxidase .

\subsection{Effect of Beet Leaves and Stalk Juice on Total Polyphenols, MDA, TNF $\alpha$ and Antioxidant Enzymes}

The increase in GPx activity induced by the hyperlipidic diet mentioned in the previous topic was prevented when, together with the diet, the volunteer took the juice with the highest dose (Figure 3c). This behavior was not observed in the group that received the low dose juice, since after $30 \mathrm{~min}$, there was an increase in GPx activity similar to the 
placebo's, and it remained high throughout the period evaluated. There were no significant differences between the groups in terms of serum concentration of the total polyphenols, MDA, CAT or TNF $\alpha$ in any of the time points analyzed (Figures $3 a, b, d$ and 4 ).

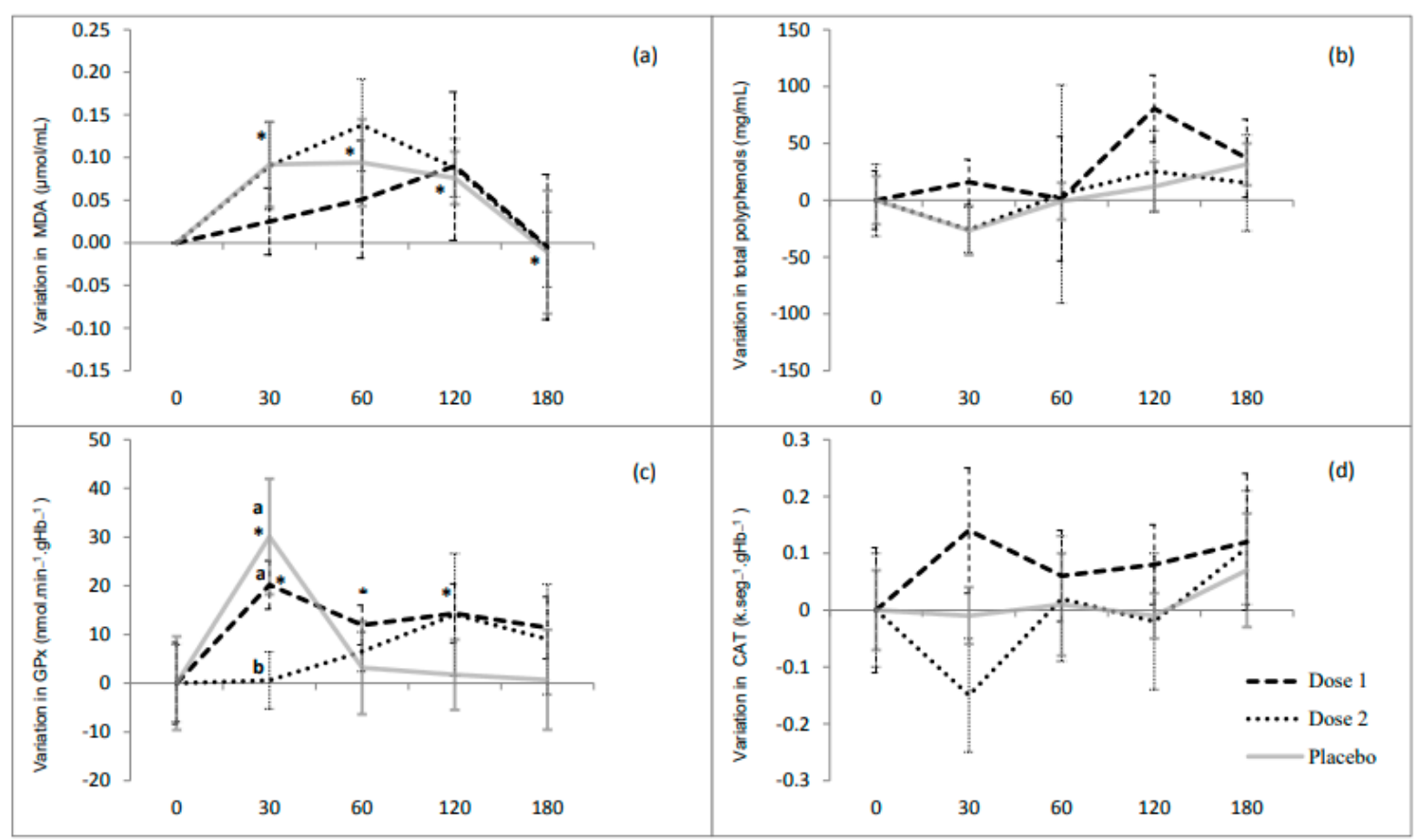

Figure 3. Variation in serum concentration of MDA (a), total polyphenols (b), GPx (c) and CAT (d) at time points of 30, 60, 120 and 180 min after ingestion of a high-fat meal in individuals with dyslipidemia, where $n=13$. Lowercase letters represent differences between groups by the factorial ANOVA test with a significance level $<5 \%$. The asterisk $\left({ }^{*}\right)$ indicates significant differences from Student's $t$ test for a sample in relation to a reference value (baseline) with Bonferroni correction and $p<0.01$. Values are expressed as mean and standard error of the mean, represented by the error bars. $\mathrm{MDA}=$ malondialdehyde $; \mathrm{GPx}=$ glutathione peroxidase $; \mathrm{CAT}=$ catalase $\mathrm{TNF} \alpha=$ tumor necrosis factor alpha.

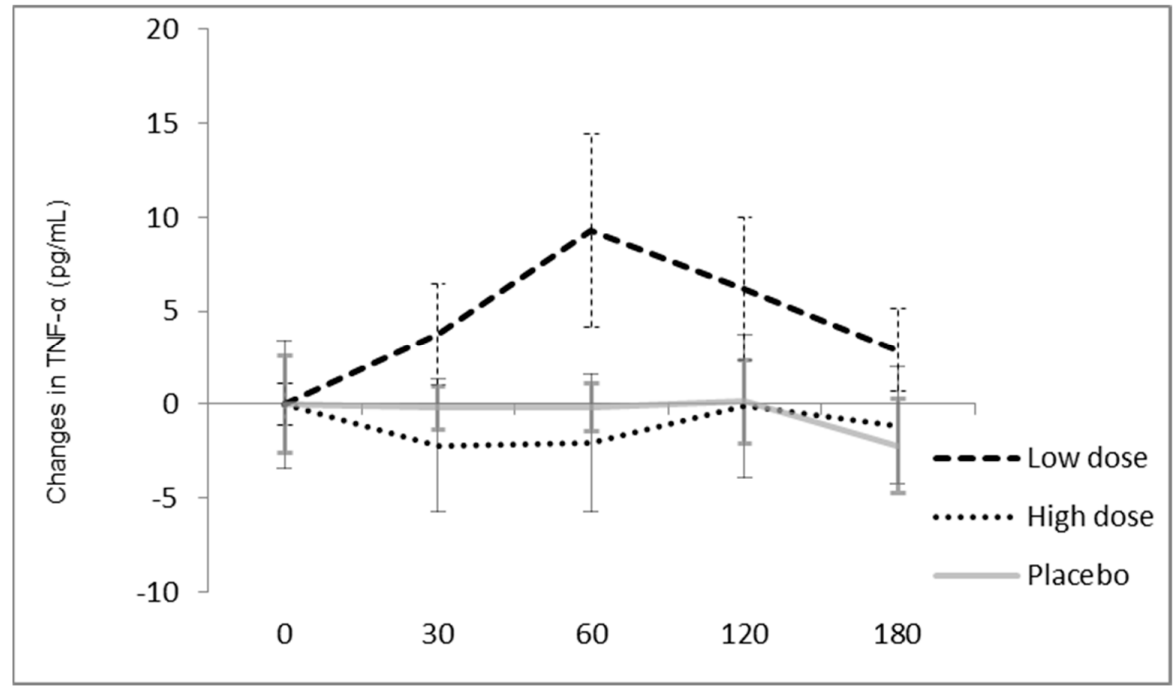

Figure 4. Variation in serum TNF $\alpha$ concentration at time points of 30, 60, 120 and 180 min after eating a high-fat meal in individuals with dyslipidemia, where $n=13$. Values are expressed as mean and standard error of the mean, represented by the error bars. TNF $\alpha=$ tumor necrosis factor alpha. 


\section{Discussion}

This is the first study to evaluate the effect of a preparation containing organic beet leaves and stalks on postprandial oxidative stress in humans. For this, we first compared the compositions of conventional and organic beet leaves and stalks to then select the best sample for the clinical trial.

A significant difference was observed in the composition of the humidity, macronutrients and polyphenols between the conventional and organic leaves and stalks. However, only the organic stalk showed a significantly higher concentration of polyphenols compared with the conventional stalks. In organic cultivation, chemicals are not used to protect against pests. Therefore, the plants synthesize phenolic compounds, which will act as a natural defense for the plant $[28,29]$, which then justifies the higher content of these compounds in the organic stems compared with the conventional ones. Regarding the carbohydrate content, the organic stalks had higher carbohydrate contents than the conventional ones, while the results found in the leaves were the opposite. One of the explanations for the greater amount of carbohydrates in organic stalks may be the fact that organically grown soils can be more balanced and fertilized, thus obtaining a greater amount of raw material for the production of nutrients by the plant [30].

Furthermore, according to Taiz and Zeiger (2013) [31], the concentration of photoassimilates, called sugars, is positively correlated with the rate of photosynthesis. As photosynthesis takes place, the products of this process are exported from photosynthetic organs (in this case, the leaves) to the regions of the plant that import photoassimilates (in this case, the stalks). In organic cultivation, there may have been a higher rate of photosynthesis and consequently greater translocation of photoassimilates from the leaves to the stems, which may explain the carbohydrate contents found in the analyses.

The fertilization method and soil nutrition can also influence the protein content found in vegetables. When the plant has nitrogen in significant amounts, protein synthesis is increased [32], which may explain the higher protein content found in organic leaves and stems compared with conventional ones. For organic cultivation, earthworms were used in the plantation. The humus produced by earthworms is considered a natural fertilizer, having nitrogen in its composition and helping to increase the production of proteins by the organic vegetable [33].

In conventional cultivation, NPK-based fertilizers are used, which are fertilizers composed of three important macro-elements for the plant, namely nitrogen, phosphorus and potassium. The nitrogen present in this fertilizer, together with phosphorus, has the purpose of increasing protein synthesis in the plant. However, the correct management of nitrogen fertilization is extremely important, since nitrogen is one of the most easily leached elements, which may explain the lower concentration of proteins in the conventional leaves and stems compared with the organic leaves and stalks despite fertilization [34].

For the lipid content, the average found in the organic and conventional leaves was $1.06 \mathrm{~g} / 100 \mathrm{~g}$ and $0.98 \mathrm{~g} / 100 \mathrm{~g}$, respectively, while in the stalks it was $0.17 \mathrm{~g} / 100 \mathrm{~g}$ for the organic ones and $0.31 \mathrm{~g} / 100 \mathrm{~g}$ for the conventional ones. These results show that these parts can be used in preparations without raising the lipid content. Furthermore, leaves and stalks, when compared with the noble part of the food, do not present significant variations from a functional point of view in the amount of this nutrient, since fruits and vegetables are not sources of lipids [35].

Due to the superiority presented by the organic leaves and stalks, the clinical study was carried out with the organic product. The major compound found in the organic BLS juice was vitexin-2-O-rhamnoside. Moreover, the organic BLS juice containing $77.5 \mathrm{mg}$ of polyphenols prevented the increase in the activity of the enzyme GPx induced by the hyperlipidic diet $30 \mathrm{~min}$ after ingestion, compared with the placebo, after a high-fat meal. In addition, the hyperlipidic meal induced hypertriglyceridemia after $120 \mathrm{~min}$ and increased MDA after $30 \mathrm{~min}$.

The vitexin-2-O-rhamnoside is a vitexin derivative flavonoid glycoside derived from apigenin found in many food sources [36]. Studies has reported that vitexin is capable of 
donating electrons and acting as a good radical scavenger and being good for antioxidant enzyme-protecting activities, which could effectively prevent cells from oxidative damage [36,37]. Considering the importance of reducing food waste, some studies $[8,19,38]$ have characterized vitexin and its derivatives as the most prominent compounds in beet leaves and stalks, highlighting the use of unconventional parts of foods in an attempt to improve the effects of unregulated intake of fatty meals.

The ingestion of high-fat meals is probably the most potent physiological factor in increasing the serum concentration of TG in the postprandial period [39]. Unlike meals rich in polyunsaturated fatty acids, meals rich in saturated fat such as the one used in the present study can stimulate transcription factors such as sterol response element-binding protein 1c (SREBP-1c), which stimulates the transcription of genes that encode multiple enzymes involved in the synthesis of fatty acids and their incorporation into TG [40]. Thus, TG and fatty acids accumulate mainly in the liver and plasma [41]. In order to assess the postprandial metabolic and hormonal response to different diets, Khoury et al. [42] conducted a randomized, controlled crossover clinical study with 10 participants and reported that a high-fat diet aggravated hypertriglyceridemia in obese individuals with dyslipidemia. Corroborating these results, Miglio et al. [43] showed an increase in the TG concentrations in 15 individuals who were overweight within $8 \mathrm{~h}$ of eating a high-fat meal.

This increase in the serum TG concentration and a probable inefficiency in the removal of triglyceride-rich lipoproteins (LRTs) can increase the inflammatory process and intensify the increase of reactive species in the postprandial period, consequently leading to oxidative damage [44]. In the present study, the biomarker of inflammatory activity $\mathrm{TNF} \alpha$ was evaluated, which is closely associated with low-grade inflammation, systemic oxidative stress and the formation of atherosclerotic plaque in obese and dyslipidemic individuals $[45,46]$. However, there were no changes in this biomarker in the study period. A systematic review conducted by Emerson et al. (2017) [47] analyzed the degree and duration of postprandial action of five relevant inflammation biomarkers, including TNF $\alpha$. The authors reported that $70 \%$ of the studies that evaluated TNF $\alpha$ after eating a high-fat diet did not observe changes in this biomarker. The authors concluded that while TNF $\alpha$ is a good marker of low-grade inflammatory activity, it does not seem to be sufficiently responsive to a stimulus with hyperlipidic diets or might be too variable to be a reliable indicator of the inflammatory response in the immediate period after ingestion of a hyperlipidic diet.

On the other hand, in our study, the high-fat diet caused an increase in oxidative damage, demonstrated by the increase in MDA in patients who ingested the placebo, similar to other studies conducted with dyslipidemic individuals $[48,49]$. The increase in ROS production, evidenced by this increase in MDA, may lead to the activation of NF-E2-related factor 2 (Nrf2), which will promote the transcription of genes that encode antioxidant enzymes [50], increasing the activity of these enzymes. There was a significant increase in GPx activity in the placebo group $(p=0.026)$ and an attenuation of this increase in the high dose group $(p=0.045)$.

Some polyphenols have $\alpha, \beta$-unsaturated carbonyl groups that function as electrophiles, allowing them to act as indirect antioxidants, which might boost the activation of Nrf2 [51], a fact that can be evidenced when evaluating the intragroup GPx activity in the low dose group at time points of $30 \mathrm{~min}(p=0.001)$ and $60 \mathrm{~min}(p=0.012)$. On the other hand, the attenuation of this increase in the high dose group suggests that a higher concentration of polyphenols, especially vitexin-2-O-rhamnoside-related compounds, present in the juice may have conferred a protection mechanism by sequestering reactive species before the activation of Nrf2, thus keeping the GPx activity close to a baseline level, as evidenced in other studies [51-54].

Macedo et al. [52] evaluated the effect of three doses of wine with different concentrations of polyphenols on inflammation and oxidative stress in adult rats for 4 weeks and also showed that the treatment with wine containing the highest concentration of polyphenols acted directly on ROS, protecting cells from oxidative damage without increasing enzyme activity. Likewise, Fustinoni-Reis et al. (2016) [53] and Cunha and Arruda 
(2017) [54] evaluating the effect of tucum-do-cerrado (Bactris setosa Mart.) on oxidative stress induced by iron accumulation in adult rats and also observed that the polyphenols present in the fruit reduced the requirement for enzymatic antioxidant function through the above-mentioned mechanism.

The strengths of the present study include the crossover experimental design carried out and the possibility of using the totality of the food to contribute to the treatment of specific health conditions, such as dyslipidemia. Since dyslipidemia is a risk factor for the development of cardiometabolic diseases, which in turn is responsible for high mortality rates worldwide, the consumption of foods as easily accessible as beets could be an important strategy to help control these risk factors. On the other hand, some limitations to this study include the absence of biochemical analysis of other inflammatory and oxidative stress biomarkers such as interleukin- 6 and 10 in a greater number of volunteers as well as isoprostanes and polyphenols in the urine and feces.

\section{Conclusions}

We concluded that the beet leaves and stalk juice may have modulated one of the postprandial enzymatic antioxidant defense mechanisms in individuals with dyslipidemia. It is important to note that these findings may not be generalizable to other groups, and further studies should be carried out with a larger sample and an experimental design that includes chronic use in order to expand the results found and strengthen the evidence of the use of the integrality of this food in promoting health and preventing diseases.

Author Contributions: Conceptualization, A.C.d.O., A.P.O.G. and P.B.B.; formal analysis, A.C.d.O., A.P.O.G. and R.d.S.C.; funding acquisition, P.B.B.; investigation, A.C.d.O., A.P.O.G., L.C.R., R.d.S.C., T.M.S., M.A.C.S., M.A.R., K.G.M. and L.C.C.; methodology, A.C.d.O., A.P.O.G., L.C.R. and P.B.B.; project administration, P.B.B.; software, R.M.S.; supervision, M.A.H. and P.B.B.; writing-original draft, A.C.d.O.; writing-review and editing, A.P.O.G., L.C.R., R.d.S.C., T.M.S., R.M.S., M.A.C.S., M.A.H., M.A.R., K.G.M., L.C.C. and P.B.B. All authors have read and agreed to the published version of the manuscript.

Funding: This research was funded by National Council for Scientific and Technological Development (CNPq) (432438/2016-5).

Institutional Review Board Statement: This study was performed in accordance with the principles recommended in the Declaration of Helsinki. The main project of this study was submitted to the Research Ethics Committee Involving Human Beings at the Federal University of Goiás (UFG) (692.586, CAAE 30274214.0.0000.5083). The clinical trial was also registered in the Brazilian Registry of Clinical Trials (ReBEC) (RBR-59bm68).

Informed Consent Statement: Written informed consent was obtained from all subjects to publish this paper.

Acknowledgments: We would like to thank the students and staff from the Center for Studies and Research on Toxic-Pharmacology (NEPET) and Laboratory of Pharmacology and Cell Toxicology (FARMATEC) of the College of Pharmacy of the Federal University of Goiás, the Laboratory of Immunology and Inflammation (LIMI) and the Coordination for the Improvement of Higher Education Personnel (CAPES) for the scholarships awarded.

Conflicts of Interest: The funders had no role in the design of the study; in the collection, analyses, or interpretation of data; in the writing of the manuscript, or in the decision to publish the results.

\section{References}

1. Burton-Freeman, B. Postprandial metabolic events and fruit-derived phenolics: A review of the science. Br. J. Nutr. 2010, 104, S1-S14. [CrossRef] [PubMed]

2. Lacorix, S.; Rosiers, C.; Tardif, J.C.; Nigam, A. The role of oxidative stress in postprandial endothelial dysfunction. Nutr. Res. Rev. 2012, 25, 288-301. [CrossRef] [PubMed]

3. Chan, D.C.; Pang, J.; Romic, G.; Watts, G.F. Postprandial Hypertriglyceridemia and Cardiovascular Disease: Current and Future Therapies. Curr. Atheroscler. Rep. 2013, 15, 309. [CrossRef] [PubMed] 
4. Katsanos, C.S. Clinical Considerations and Mechanistic Determinants of Postprandial Lipemia in Older Adults. Adv. Nutr. Int. Rev. J. 2014, 5, 226-234. [CrossRef]

5. Masuda, D.; Yamashita, S. Postprandial Hyperlipidemia and Remnant Lipoproteins. J. Atheroscler. Thromb. 2017, 24, 95-109. [CrossRef]

6. Mirmiran, P.; Houshialsadat, Z.; Gaeini, Z.; Bahadoran, Z.; Azizi, F. Functional properties of beetroot (Beta vulgaris) in management of cardio-metabolic diseases. Nutr. Metab. 2020, 17, 3. [CrossRef]

7. Silva, L.G.S.; Morelli, A.P.; Pavan, I.C.P.; Tavares, M.R.; Pestana, N.F.; Rostagno, M.A.; Simabuco, F.M.; Bezerra, R.M.N. Protective effects of beet (Beta vulgaris) leaves extract against oxidative stress in endothelial cells in vitro. Phytother. Res. 2020, 34, 1385-1396. [CrossRef]

8. Lorizola, I.M.; Miyamoto, J.; Vieira, A.L.F.; Sumere, B.R.; Bezerra, R.M.N.; Torsoni, M.A.; Torsoni, A.S.; Rostagno, M.A.; Milanski, M.; Capitani, C.D. Beet (Beta vulgaris L.) stalk and leaf supplementation changes the glucose homeostasis and inflammatory markers in the liver of mice exposed to a high-fat diet. Food Chem. Mol. Sci. 2021, 2, 100018. [CrossRef]

9. Nurdiana, S.; Goh, Y.M.; Ahmad, H.; Dom, S.M.; Azmi, N.S.; Zin, N.S.N.M.; Ebrahimi, M. Changes in pancreatic histology, insulin secretion and oxidative status in diabetic rats following treatment with Ficus deltoidea and vitexin. BMC Complement. Altern. Med. 2017, 17, 290. [CrossRef]

10. He, M.; Min, J.-W.; Kong, W.-L.; He, X.-H.; Li, J.-X.; Peng, B.-W. A review on the pharmacological effects of vitexin and isovitexin. Fitoterapia 2016, 115, 74-85. [CrossRef]

11. Hallmanna, E.; Rozparab, E.; Słowianekc, M.; Leszczyńskac, J. The effect of organic and conventional farm management on the allergenic potency and bioactive compounds status of apricots (Prunus armeniaca L.). Food Chem. 2019, 279, 171-178. [CrossRef] [PubMed]

12. Carrillo, C.; Wilches-Peres, D.; Hallmann, E.; Kazimierczak, R.; Rembiałkowska, E. Organic versus conventional beetroot. Bioactive compounds and antioxidant properties. LWT 2019, 116, 108552. [CrossRef]

13. Burri, S.C.M.; Ekholm, A.; Håkansson, Å.; Tornberg, E.; Rumpunen, K. Antioxidant capacity and major phenol compounds of horticultural plant materials not usually used. J. Funct. Foods 2017, 38, 119-127. [CrossRef] [PubMed]

14. Pregnolato, W.; Pregnolato, N.P. Normas Analíticas do Instituto Adolf Lutz; Instituto Adolf Lutz: São Paulo, Brazil, 1985.

15. Kjeldahl, J.G.C.T. Neue Methodezur Bestimmung des Stickstoffs in organis chen Körpern. Fresenius Z. Anal. Chem. 1883, 22, 366-382. [CrossRef]

16. Association of Official Agricultural Chemists-AOAC. Official Methods of Analysis, 14th ed.; Arlington (VA): Washington, DC, USA, 1984; p. 1141.

17. Bligh, E.G.; Dyer, W.J. A rapid method of total lipid extraction and purification. Can. J. Biochem. Physiol. 1959, 37, 911-917. [CrossRef]

18. Singleton, V.L.; Orthofer, R.; Lamuela-Raventós, R.M. Analysis of total phenols and other oxidation substrates and antioxidants by means of folin-ciocalteu reagent. Methods Enzymol. 1999, 299, 152-178. [CrossRef]

19. Gomes, A.P.O.; Ferreira, M.A.; Camargo, J.M.; Araújo, M.D.O.; Mortoza, A.S.; Mota, J.F.; Coelho, A.S.G.; Capitani, C.D.; Coltro, W.K.T.; Botelho, P.B. Organic beet leaves and stalk juice attenuates HDL-C reduction induced by high-fat meal in dyslipidemic patients: A pilot randomized controlled trial. Nutrition 2019, 65, 68-73. [CrossRef]

20. Xavier, H.T.; Izar, M.C.; Faria Neto, J.R.; Assad, M.H.; Rocha, V.Z.; Sposito, A.C.; Fonseca, F.A.; dos Santos, J.E.; Santos, R.D.; Bertolami, M.C.; et al. V Diretriz Brasileira de Dislipidemias e Prevenção da Aterosclerose. Arq. Bras. Cardiol. 2013, 101, 1-22. [CrossRef]

21. Adzic, M.; Niciforovic, A.; Vucic, V.; Neskovic-Konstantinovic, Z.; Spasic, S.D.; Jones, D.R. Systemic NF-kB activation in blood cells of breast cancer patients. Redox. Rep. 2006, 11, 39-44. [CrossRef]

22. Heyward, V.H.; Stolyk, L.M. Avaliação da Composição Corporal Aplicada, 1st ed.; Manole: São Paulo, Brazil, 2000.

23. Serafini, M.; Maiani, G.; Ferro-Luzzi, A. Alcohol-free red wine enhances plasma antioxidant capacity in humans. J. Nutr. 1998, 128, 1003-1007. [CrossRef]

24. Antunes, M.V.; Lazzaretti, C.; Gamaro, G.D.; Linden, R. Preanalytical and validation studies for the determination of malondialdehyde in human plasma through high performance liquid chromatography after derivatization with 2,4-dinitrophenylhydrazine. Rev. Bras. Ciências Farm. 2008, 44, 279-287. [CrossRef]

25. Aebi, H. Catalase in vitro. In Methods in Enzymology, 1st ed.; Academic Press: New York, NY, USA, 1984; Volume 105, pp. 121-126.

26. Flohé, L.; Günzler, W.A. Assays of glutathione peroxidase. Methods Enzymol. 1984, 105, 114-120. [CrossRef] [PubMed]

27. Rosner, B. Fundamentals of Biostatistics, 7th ed.; Broke/Colen: Boston, MA, USA, 2011.

28. Mditshwa, A.; Magwaza, L.; Tesfay, S.Z.; Mbili, N. Postharvest quality and composition of organically and conventionally produced fruits: A review. Sci. Hortic. 2017, 216, 148-159. [CrossRef]

29. Huber, M.; Rembiałkowska, E.; Średnicka-Tober, D.; Bügel, S.; van de Vijver, L. Organic food and impact on human health: Assessing the status quo and prospects of research. NJAS-Wagening J. Life Sci. 2011, 58, 103-109. [CrossRef]

30. Mie, A.; Andersen, H.R.; Gunnarsson, S.; Kahl, J.; Kesse-Guyot, E.; Rembiałkowska, E.; Quaglio, G.; Grandjean, P. Human health implications of organic food and organic agriculture: A comprehensive review. Environ. Health 2017, 16, 111. [CrossRef]

31. Taiz, L.; Zeiger, E. Fisiologia Vegetal, 5th ed.; Artmed: Porto Alegre, Brazil, 2013.

32. Worthington, V. Nutritional Quality of Organic Versus Conventional Fruits, Vegetables, and Grains. J. Altern. Complement. Med. 2001, 7, 161-173. [CrossRef] 
33. Pathma, J.; Sakthivel, N. Microbial diversity of vermicompost bacteria that exhibit useful agricultural traits and waste management potential. SpringerPlus 2012, 1, 26. [CrossRef]

34. Lim, S.L.; Wu, T.Y.; Lim, P.N.; Shak, K. The use of vermicompost in organic farming: Overview, effects on soil and economics. J. Sci. Food Agric. 2014, 95, 1143-1156. [CrossRef]

35. Storck, C.R.; Nunes, G.L.; De Oliveira, B.B.; Basso, C. Leaves, stalk, pell and seeds of vegetables: Nutritional composition, utilization and sensory analysis in food preparations. Ciência Rural 2013, 43, 537-543. [CrossRef]

36. Peng, Y.; Gan, R.; Li, H.; Yang, M.; McClements, D.J.; Gao, R.; Sun, Q. Absorption, metabolism, and bioactivity of vitexin: Recent advances in understanding the efficacy of an important nutraceutical. Crit. Rev. Food Sci. Nutr. 2020, 61, 1049-1064. [CrossRef]

37. Babaei, F.; Moafizad, A.; Darvishvand, Z.; Mirzababaei, M.; Hosseinzadeh, H.; Nassiri-Asl, M. Review of the effects of vitexin in oxidative stress-related diseases. Food Sci. Nutr. 2020, 8, 2569-2580. [CrossRef] [PubMed]

38. Lorizola, I.M.; Furlan, C.P.B.; Portovedo, M.; Milanski, M.; Botelho, P.B.; Bezerra, R.M.N.; Sumere, B.R.; Rostagno, M.; Capitani, C.D. Beet Stalks and Leaves (Beta vulgaris L.) Protect Against High-Fat Diet-Induced Oxidative Damage in the Liver in Mice. Nutrients 2018, 10, 872. [CrossRef] [PubMed]

39. Niki, E. Lipid peroxidation: Physiological levels and dual biological effects. Free Radic. Biol. Med. 2009, 47, 469-484. [CrossRef] [PubMed]

40. Horton, J.D.; Shah, N.A.; Warrington, J.A.; Anderson, N.N.; Park, S.W.; Brown, M.S.; Goldstein, J.L. Combined analysis of oligonucleotide microarray data from transgenic and knockout mice identifies direct SREBP target genes. Proc. Natl. Acad. Sci. USA 2003, 100, 12027-12032. [CrossRef]

41. Moon, Y.-A.; Liang, G.; Xie, X.; Frank-Kamenetsky, M.; Fitzgerald, K.; Koteliansky, V.; Brown, M.S.; Goldstein, J.L.; Horton, J.D. The Scap/SREBP Pathway Is Essential for Developing Diabetic Fatty Liver and Carbohydrate-Induced Hypertriglyceridemia in Animals. Cell Metab. 2012, 15, 240-246. [CrossRef]

42. El Khoury, D.; Hwalla, N.; Frochot, V.; Lacorte, J.-M.; Chabert, M.; Kalopissis, A.D. Postprandial metabolic and hormonal responses of obese dyslipidemic subjects with metabolic syndrome to test meals, rich in carbohydrate, fat or protein. Atherosclerosis 2010, 210, 307-313. [CrossRef]

43. Miglio, C.; Peluso, I.; Raguzzini, A.; Villaño, D.V.; Cesqui, E.; Catasta, G.; Toti, E.; Serafini, M. Antioxidant and inflammatory response following high-fat meal consumption in overweight subjects. Eur. J. Nutr. 2012, 52, 1107-1114. [CrossRef]

44. Krüger, R.L.; Farinha, J.B.; Teixeira, B.C.; Reischak-Oliveira, A. Estresse oxidativo e a função endotelial: Efeitos do exercício físico associado à lipemia pós-prandial. J. Vasc. Bras. 2015, 14, 328-340. [CrossRef]

45. Tangvarasittichai, S. Oxidative stress, insulin resistance, dyslipidemia and type 2 diabetes mellitus. World J. Diabetes 2015, 6 , 456-480. [CrossRef]

46. Jung, U.J.; Choi, M.-S. Obesity and Its Metabolic Complications: The Role of Adipokines and the Relationship between Obesity, Inflammation, Insulin Resistance, Dyslipidemia and Nonalcoholic Fatty Liver Disease. Int. J. Mol. Sci. 2014, 15, 6184-6223. [CrossRef]

47. Emerson, S.R.; Kurti, S.P.; Harms, C.A.; Haub, M.D.; Melgarejo, T.; Logan, C.; Rosenkranz, S.K. Magnitude and Timing of the Postprandial Inflammatory Response to a High-Fat Meal in Healthy Adults: A Systematic Review. Adv. Nutr. Int. Rev. J. 2017, 8, 213-225. [CrossRef] [PubMed]

48. Burton-Freeman, B.; Linares, A.; Hyson, D.; Kappagoda, T. Strawberry Modulates LDL Oxidation and Postprandial Lipemia in Response to High-Fat Meal in Overweight Hyperlipidemic Men and Women. J. Am. Coll. Nutr. 2010, 29, 46-54. [CrossRef] [PubMed]

49. Lim, Y.; Lee, K.W.; Kim, J.Y.; Kwon, O. A beverage of Asiatic plantain extracts alleviated postprandial oxidative stress in overweight hyperlipidemic subjects challenged with a high-fat meal: A preliminary study. Nutr. Res. 2013, 33, 704-710. [CrossRef] [PubMed]

50. Tebay, L.E.; Robertson, H.; Durant, S.T.; Vitale, S.R.; Penning, T.M.; Dinkova-Kostova, A.T.; Hayes, J.D. Mechanisms of activation of the transcription factor Nrf2 by redox stressors, nutrient cues, and energy status and the pathways through which it attenuates degenerative disease. Free Radic. Biol. Med. 2015, 88, 108-146. [CrossRef]

51. Pereira, A.C.D.S.; Dionísio, A.P.; Wurlitzer, N.; Alves, R.E.; de Brito, E.S.; Silva, A.; Brasil, I.M.; Filho, J.M. Effect of antioxidant potential of tropical fruit juices on antioxidant enzyme profiles and lipid peroxidation in rats. Food Chem. 2014, 157, 179-185. [CrossRef]

52. Macedo, L.F.L.; Rogero, M.M.; Guimarães, J.P.; Granato, D.; Lobato, L.P.; Castro, I.A. Effect of red wines with different in vitro antioxidant activity on oxidative stress of high-fat diet rats. Food Chem. 2013, 137, 122-129. [CrossRef]

53. Fustinoni-Reis, A.M.; Arruda, S.F.; Dourado, L.P.S.; Da Cunha, M.S.B.; Siqueira, E.M.A. Tucum-Do-Cerrado (Bactris setosa Mart.) Consumption Modulates Iron Homeostasis and Prevents Iron-Induced Oxidative Stress in the Rat Liver. Nutrients 2016, 8, 38. [CrossRef]

54. Cunha, M.D.S.B.D.; Arruda, S.F. Tucum-do-Cerrado (Bactris setosa Mart.) May Promote Anti-Aging Effect by Upregulating SIRT1-Nrf2 Pathway and Attenuating Oxidative Stress and Inflammation. Nutrients 2017, 9, 1243. [CrossRef] 